condition which obtains exceptionally in the spots. The "granulated" texture of the photosphere is the result of the eruptive pressure of the internal hydrogen, upheaving and penetrating the glowing mass of iron. The faculæ owe their greater elevation and intensity to an increased activity of the same process; and the chromosphere and the protuberances, whether of the more eruptive or more cloudy character, are traceable to the same origin, the greater brilliancy of the former class being due to the admixture of metallic vapours with the all-pervading hydrogen. The iron shell is not everywhere in a state of equal fluidity, a considerable portion being in a more "pappy." or viscous condition, such as may be seen in our own iron furnaces, which, however, does not render its presence manifest without such a reduction of temperature as to produce opacity. This cooling does not obtain either in the equatorial or polar regions, but is effected in what are known as the "spotted zones," by the overflow of hydrogen from the loftier equatorial strata of the atmosphere. Here, the gas, having been carried up in consequence of the solar rotation into a higher and cooler region, and extending itself laterally as an " equatorial current," descends on the less fluid portions of the photosphere, whence radiation is not so free; they are thus reduced to the more scoriaceous and opaque condition in which they assume the well-known appearance of "spots," while the whirls of cooler vapour on the outside of the main column in its downpour, encountering and tearing away the adjacent metallic edges of the chromosphere, force them to assume the form of those radiated fringes which we know as "penumbræ." The maxima and minima of the spots, as well as their respective drifting towards the poles or the equator, find their explanation in a "pulsation" or alternite compression and expansion of the globe, chiefly in the direction of its axis, from corresponding alternations in the balance of internal condensation and temperature, each of which is supposed to be in its turn in the ascendant; and though the change of dimension is slight, it is sufficient to give preponderance either to the equatorial or polar current, and, combined with the rotation, to determine the periodicity of the frequency and range of the spots. On the whole, the energy of solar radiation is never compensated ; but the waste is so gradual that we have no reason to anticipate any sensible effect for ages to come, and yet so sure that the progressive cooling must terminate in ultimate extinction. In our author's words, "When in some future period of the world the whole of the hydrogen has escaped from the solar nucleus, the sun will cease to shine with its wonted intensity, and will become more and more feeble till at length it hangs in the firmament, a mighty globe of glowing red, as seen from other worlds a ruddy star, which, through rapid cooling, becomes visibly obscured, and, from the formation of everywhere surrounding scoriæ, immersed in deep night,"- - a termination of which it may be said that, whatever its intrinsic probability, no reader need look forward to it with the slightest personal apprehension. And were that resplendent body, as Kepler in the exuberance of his imagination believed, the abode of glorious spirits, they might perhaps be supposed to smile at all such anticipations as utterly foreign to the unsearchable designs of the All-wise Creator.

And yet we may not forget that there have been, from time to time, mysterious warnings among the innumerable suns that have their abode in the far depths of space, and we are reminded by no process of argument, but by the evidence of our senses, how untrue it is that "all things continue as they were from the beginning of the creation." The certainty of strange and wonderful catastrophes of outburst or extinction has come to our knowledge, though perhaps only after centuries, or it may have been ages, of the transmission of the recording light: and similar events, to be recognised only by long-distant generations, may be in progress at the present hour. We know very little of the history of the universe, and it becomes us well to speak of such possibilities with caution and reverence. Meanwhile we owe a debt to all who will aid us in the attempt to gratify a very natural curiosity, and to our author among the rest. Some portion of his hypothesis does not come before us for the first time. La Hire in very early days entertained the notion of opaque bodies floating in a fluid mass and occasionally appearing on its surface; and the conclusions of Gautier were very similar as to a partial solidification of metal in fusion; but we must bear in mind that it is only for the diffusion of hydrogen through a liquid envelope of iron that our author claims originality. His ideas are expanded and enforced by so much elaborate reasoning as at any rate to deserve perusal, if they do not succeed in producing conviction. As to this point we may freely confess that the author is more sanguine than ourselves. Some of his arguments are well worthy of attention; but the general character of the treatise is that of an ingenious piece of special pleading, one-sided, but fair and honest in its selfpersuasion. A few omissions and mistakes might be pointed out, but they do not impair his argument. The weakness of this, as our readers will have already perceived, lies in the magnitude of some of its assumptions. It might indeed be said that the same objection lies against each of the more commonly received theories; and to this it can only be replied that, though similar in character, it differs in amount; and that the value of any attempt at explanation must be estimated in the inverse ratio of its unproved demands upon our assent.

T. W. WEBB

\section{THE EARTHQUAKE}

I $\mathrm{N}$ a previous notice (p. 17) brief mention was made of the more obvious conclusions which follow from a consideration of the observed effects of the earthquake of April 22. Mention was also made of some points upon which further knowledge would be of value, notably as to the result of the earthquake upon wells and springs. Mr. De Rance's letters give important information upon this matter.

The measurements of the water in wells at Colchester and Bocking prove that the level of the water has risen seven feet in the former case and from twenty to thirty inches in the latter case. These facts, and also the curious instance of water spouting from the ground at East Mersea, are quite in accord with what frequently occurs during earthquakes. Mr. Mallet says:- "Fissures containing water often spout it up at the moment of shock. Wells, after the shock, alter their water-level, and sometimes the nature of their contents ; springs become altered in the volume of water they deliver. . . . It is important to observe whether any changes of level of water in wells take place prior to earthquakes. Statements to this effect have frequently been made, but as yet stand much in need of confirmation."

Dr. Taylor's observations that the new and often slightly-built houses have generally suffered less than the old and more solid structures is scarcely what one would have expected. In districts much subject to earthquakes the houses are generally built in such a manner that they yield readily to the vibration, and so mostly escape serious damage. Mr. Mallet indeed believes that if this custom were enforced very little damage would be done. As regards larger and more important structures, the question is not so easily settled; and Messrs. D. and T. Stevenson, in constructing the lighthouses of Japan, employed a peculiar and ingenious contrivance for guarding against the effects of earthquake shocks: this was to interpose a break in the rigid part of the building, and so to prevent the propagation of the shock. Mr. D. Stevenson, in describing this, says :- "The plan I propose for this purpose, which may for brevity be termed an aseismatic joint, is 
the introduction of spherical balls of bell-metal working in cups of the same material placed between two platforms, the lower cups being fixed to beams forming the foundation, and the upper cups being fixed to the lower beams of the superstructure, thus admitting, within a limited range, free motion of the upper over the lower part of the building." The cost of this was about gol. for each lighthouse.

This plan had some disadvantages : high winds, for instance, gave as much free motion to the upper part as a slight earthquake would do ; and there was also consider-

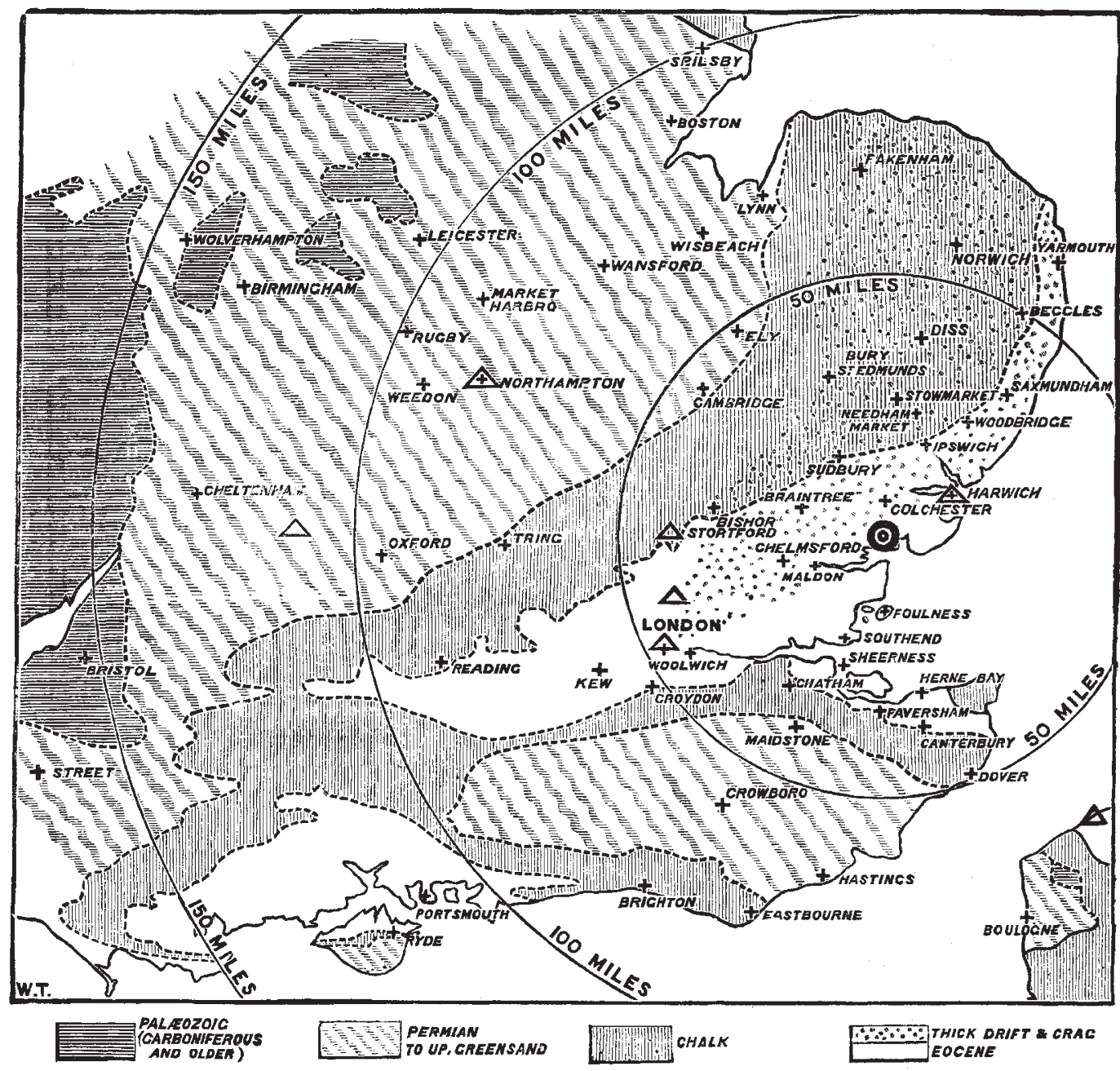
PALAEOZOIC ROCKS
PROVED BY BORING

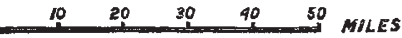

() central area

Map of the Earthquake of April 22, 1884 . N.B.-The places marked are those at which the shock was filt. In the East of England only the more important of such places are marked.

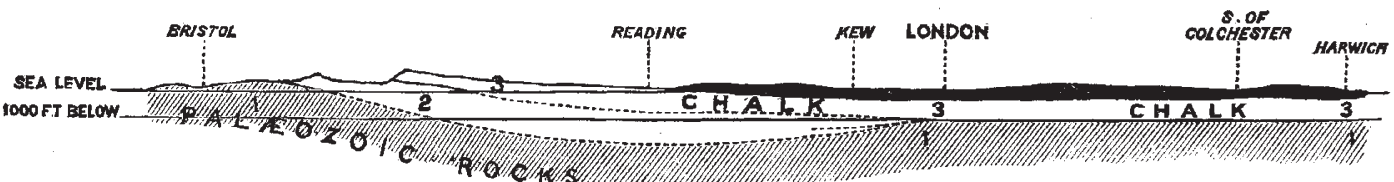

Section from Bristol to Harwich, showing the probable range of the Palæozoic Rocks. I, Palæozoic Rocks (Carbonifer us and Older); 2, Permian to Upper Greensand; 3, Chalk.

able movement of the lights during cleaning. The light- structing the lighthouses with "great weight and solidity, house-keepers, therefore, screwed up the metal plates, so thereby adding to their inertia and checking the oscillathat when an earthquake came sufficiently powerful to tion." Mr. W. Lloyd, from his experience in South test the value of the plan, the structure was rigid and the America, believes that the more solid the structures the glasses were broken. This plan was afterwards aban- better they resist earthquake shocks. Mr. Woods, on the doned, and Mr. R. H. Brunton adopted the plan of con- other hand, found that in Peru lightly-built structures of 
iron were unharmed by earthquake shocks which did enormous damage to other buildings. This apparent contradiction may perhaps be explained by supposing that a lightly-built structure would give to every movement, and a very massively-built structure would resist such movement; either would bear a considerable earthquake shock unharmed, but buildings of intermediate resisting power would be destroyed.

Upon the twisting motion often noticed in earthquakes, and especially referred to by Dr. Taylor as observed at Langenhoe, Peldon, Fingrinhoe, and Abberton, much difference of opinion has existed. From the time of Aristotle it has been commonly attributed to a vorticose movement of the earth's surface at the part affected. The effects produced seem at first quite to accord with this explanation, as when in Japan a chimney ten feet high, and two feet by three, is broken in two, the upper half being twisted diagonally round without other fracture or displacement; or when, at Mendoza, a church tower has its lower story uninjured, its middle story tumed through an angle of nearly $90^{\circ}$, and its highest story thrown completely over. But Mr. Mallet, who recorded similar cases in the Neapolitan earthquake of 1857 , clenied that this is in any case the correct explanation, and he believed that the twisting is best explained by resolved motions, due to the transit rectilinearly of the shock.

As regards the range of the recent earthquake very little more is known than was recorded during the first few days after the shock. The most important new fact is that mentioned by Dr. Prince of the shock being observed at Crowborough in Sussex; this proves that the Wealden area was affected, a!though the shock must have been very slight. Probably if the Palæozoic rocks were as near the surface there as was once hoped the shock would have been more distinctly felt.

There can now be little doubt that the origin of the shock was vertically under West Mersea or thereabouts, and that the wave must have travelled in all directions away from that area, but not necessarily with equal force and rapidity in all directions. The observations as to the direction of motion generally agree with this view; but in the neighbourhood of London there are some curious differences. The observations in London itself generally give an east and west direction, whereas some on the north side of London appear to point to a more north and south direction.

No observations are recorded of the connection of the earthquake wave with minor details of geological structure, such as the outcropping of certain hard or soft beds, or with lines of fault. The only instance of the latter kind known to me is at St. John's, near Greenwich, where the shock was felt very close to a fault, well cxposed in the railway cutting just west of St. John's Station. But another and perhaps better explanation is that the shock was there felt by an invalid lying quietly in bed, and very sensitive to movement.

In the map here given, an attempt has been made to mark the positions of all places at which the shock was felt, so far as can be learnt from published accounts; but in Esscx, Suffolk, and North Kent only a few of such places could be marked. By marking the outcrops of the older rocks (Carboniferous and earicr), the possible connection of these with the travel of the earthquake wave may be seen. This is made clearer by the section. The position of the Palæozoic rocks is known at Harwich and London; there is some uncertainty as to their position under Reading and Colchester, but for the purpose intended, and resard being had to the depth at which the shock must have originated (certainly far within the Palcozoic rocks), the line drawn is sufficiently near the truth. We can see how the shock can have been propagated throtigh the hard Palæozoic rocks and been felt where these are bare or thinly covcred with newar rocks, whereas through the thick and softer Sscondary and Tertiary rocks the wave might travel a shorter distance, Possibly also this section may suggest an explanation of the double shock which was sometimes recorded : the first would be that travelling quickly through the hard Palæozoic rocks, the second that propagated more slowly through the softer ovcrlying newer rocks.

W. TOPLEY

\section{VOLCANOES ON THE SHORES OF LAKE NYASSA, AFRICA}

D. LAWS, on his return to Europe from the mission station at the north end of Lake Nyassa, passed by Naples, where I had the pleasure of meeting him. Amongst other information that I gleaned was that pumice-stone is very abundant in the locality above-mentioned and on the shores of the lake, where pebbles of coal are also met with. He also informed me that many of the rocks had a striking resemblance to the volcanic tufas around Naples. Dr. Laws happened to have a specimen of pumice, which he kindly placed at my disposal.

The specimen forms about two-thirds of a flattened ellipsoidal pebble of about $\mathrm{I}_{2}^{\frac{1}{2}} \times \mathrm{I} \frac{1}{4} \times \frac{3}{4}$ inches in diameter. It is of a dirty buff colour, darker in spots, the result of oil stains in packing. The grain is fine ; there are very few large cavities, which arc multilocular, with smooth-walled spheroidal-shaped alveoli. The specific gravity of the mass is light. The characters indicate great homogeneity of material, only a moderate amount of dissolved water in the original magma, and an eruption of true paroxysmal type. A few minute crystals of sanadin are discernible with the naked eye, and rarely also a small black spot, which we shall see to be pyroxene.

It is easily scctionised, and when examined under a low power, shows a remarkable uniformity of size in the pores. Those near and opening upon the surface contain a few diatoms indicating the action of water as the cause of the pebble-like form.

The magma is a perfect glass of light straw-colour. Scattered through it are a few small irregular crystals of sanadin, fairly clear, but of irregular boundaries in many cases, as if they had wavered between crystallisation and fusion. A few are twinned on the Carlsbad type, and a few also present fine wavy striation parallel to their longer axis. At one spot were two or three sanadin crystals inclosing dark brownish-green pleochroic microliths, too irregular to measure the angle of extinction, but which looked very much like amphibole. There were to be seen a few well-formed crystals of pyroxene of light pea-green colour, quite free from pleochroism, and with characteristic crystalline boundaries and cleavage, with absence of inclosures. In the immediate neighbourhood of the large pyroxene crystals were a few microliths of the same mineral; the average angle of extinction was $49^{\circ}$, and ranging within narrow limits. No other "formed" materials were discernible exccpt a mass of dirty brown, dusty matter involved in a group of sanadin crystals, which might be magnetite. The whole character of the specimen is strikingly like some of the basic pumices of Monte Somma, and almost indistinguishable from some specimens of Phase VI. Period $\mathrm{i}$ (Quart. Fourn. Geol. Soc., January I 884).

I regret that for want of a balance I have not been able to analyse the specimen, though I am inclined to place it amongst volcanic rocks containing less than 55 per cent. of silica.

The specimen itsclf is in no way remarkable, but it is interesting as indicating the existence of continental volcanoes some hundreds of miles from the seashore, although in the immediate neighbourhood of a great lake, as also an additional grain of acquaintance with the geology of the mysterious interior of the "dark continent."

My informant has promised to forward me a collec. 